\title{
Language culture of a city in cyberspace
}

\author{
Svetlana Dvinina ${ }^{1, *}$, and Svetlana Pitina ${ }^{1}$ \\ ${ }^{1}$ Chelyabinsk State University, Department of Theoretical and Applied Linguistics, 129, Bratiev Khashirinykh, 454001, \\ Chelyabinsk, Russia
}

\begin{abstract}
The article attempts at studying language culture of a city on the material of the two leading websites, www.74.ru of Chelyabinsk and www.66.ru of Yekaterinburg. The choice of websites of the two main Ural cities is conditioned by their geographical position, similar role in the country as leading industrial centres. Language and cultural approach to website study has resulted in revealing general and special characteristics of the local city space and city image. Cognitive and discourse approach to city cyberspace research has shown the tendencies to choose both local and global issues for discussion widening the boarders of the local city culture by including actual issues for Russia and the whole world. Place names, local place names and city space verbal markers are frequently used in both websites creating true to life language and cultural message for the websites users, making city image recognizable and language culture of a city specific by using a few folk place names. City space markers have been outlined and grouped. The sites are characterized by similar content representation but differ in its realization. Diagrams and tables help verify the results of the city space analysis and website dynamics
\end{abstract}

\section{Introduction}

The work studies language culture of a city in local cyberspace which continues urban space research at Chelyabinsk State University by S.Yu. Dvinina [1], S.A. Pitina, G.V. Urvantsev [2]. Language culture of a city space has been successfully studied by Russian linguists R. M. Amirova [3], E. L. Berezovich [4], N. D. Golev, L. M. Dmitrieva [5], E. A. Jakovleva [6], T. V. Khvesko [7], N. A. Prokurovskaja [8], E. S. Samsonova [9], V. Superanskaja [10] and foreign linguists G. R. Stewart [11], A.V. Urazmetova, Ju. Kh. Shamsutdinova [12]. The given article focuses on analyzing Chelyabinsk and Yekaterinburg websites www.74.ru [13] and www.66.ru [14].

Universal features and local peculiarities of city space representation are revealed with the help of language and cultural approach to cyberspace. Cognitive and discourse approach allows analyzing the mental conception of a city space by its residents, its cognitive representation in written static form (articles) as well as researching its dynamic characteristics expressed by possible visual effects (photos, videos, banners, commentaries, advertisements).

Urban space is defined by the major objects specified by place names and minor place names: oikonyms (names of population clusters), ergonyms (names of commercial organizations), urban place names: godonyms (names of streets), agoronyms (names of squares), urban horonyms, (names of geographical areas and administrative districts) combining geographical position, language and cultural image of a city and personal experience of viewers. Urban space is represented by other types of verbal markers, lexical units, hyperonyms and hyponyms denoting city objects, their concrete names, city space subjects, specifications.

The present work aims at finding out common and different aspects in representing the two regional cities, Chelyabinsk and Yekaterinburg situated in the Ural, having similar historical background but currently developing in divergent ways. Language and cultural, cognitive and discourse analysis of the two websites devoted to city problems and current news can help realize the image and atmosphere of the two cities, outline significant events and places, specify the difference between official and folk place names, local and universal features, etc.

The work studies the general overview of the two websites, their navigation, news sections as well as changes in the content during a specific period. The research looks at the time period of updating, the presentation format and the content. The presentation format of city websites should take into account the unique character of the 'clip mind' generation.

\section{Materials and methods}

The website devoted to Chelyabinsk (www.74.ru) [13] begins with pop-ads 'covering' almost one third of the screen without scrolling (the experience shows that it depends on the browser). This inconvenient "intrusion" makes viewers first pay attention to information about the weather, traffic jams, currency rates, social buttons,

\footnotetext{
* Corresponding author: lana-dvinska@mail.ru
} 
log-in, constant tabs and temporary labels. The constant tabs include such topics as JOB, NEWS, AUTO, BUSINESS, REAL ESTATE, PUBLIC TRANSPORT, HEALTH, WANT ADS, CURRENT EVENTS GUIDE, FORUMS, EDUCATION, MAP, LONELY HEARTS, HOROSCOPE, and SEARCH. The left side-bar includes pop-ads, an invitation to report news, market, guided tours and then duplicates 'forums', 'map', 'lonely hearts', 'horoscope'. The central column offers 28 pieces of news chosen by editors as the most interesting, with the first one being presented as a picture (photo / collage).

The website www.66.ru [14] also offers pop-ads covering a part of the screen, followed by the constant tabs of the 66.RU site including REAL ESTATE, FINANCE, AUTO, JOB, FOOD, CURRENT EVENTS GUIDE. The same line provides information about the weather and currency rates. The prime screen contains 5 news one of which is illustrated. While scrolling the page one can notice a kind of news "bars" containing from three to four pieces of news. There are a lot of single photos, different in size, with headings. The number of advertisements is limited to two. There is only one distinct advantage of Yekaterinburg website consisting in the usage of \# which makes the search easier.

The colors of websites also play an important role as they can either attract or distract viewers. The website of Chelyabinsk is blue-and-white (red color inclusions make the website similar to the Russian flag). The website of Yekaterinburg uses olive and white colors (slightly resembling Sberbank colors) which results in creating a more comfortable visual background.

\section{Results}

\subsection{Space themes in leading website stories}

To define what space aspects are used to present the image of a city, place names and urban verbal markers accessed from the given websites have been analyzed and classified.

The website of Chelyabinsk [13] and its central news column (headings and corresponding leads-in, webpage updated on April 1, 2019) includes the following place names (italicized examples), city space verbal markers including general names of the city objects and representatives of the city population. These are South Ural (5) inhabitant, Minsots (abbreviation for the Ministry of Social Security); hospital, queue, registration desk; new building, Chelyabinsk (8); region (regional); Chelyabinsk suburbs; clinic "Medeor"; Zlatoust; city hall; land; Churilovo; RC "Zarya" (Residential Complex "Dawn"); city; City water supply system company; "Intersviaz"”; Chelyabinsk citizen (6); S7 (airlines). This also includes all the world; Ukraine; $K V N$ (abbreviation for Club for the Lightheaded and Quick-witted); daycare queue; $M M K$ (abbreviation for Magnitogorsk Iron and Steel Works); TV tower; half a $\mathrm{km}$ radius; metals, STSI (abbreviation for State Traffic Safety Inspectorate); Chelyabinsk frontier guard, police;
Chelyabinsk female inhabitant; health resort; Ussuriisk, region; apartment; Dovator market; new places; clinic; Gorzdrav (abbreviation for city healthcare); MUP (Municipal Unitary Enterprise); civil servant; tram, metals, busy road; ambulance; fire-fighters; ChelyabGET; tower-block.

The place names in the headings and leads-in present the news regarding not only the given region but the country and the world in general. The level of frequency cannot be compared: two proper names are partially connected with Chelyabinsk region $(S 7, K V N)$, and two place names (Ussuriisk, Ukraine) with another region and country. However, the fact that they are used (as well as the phrase "all the world") points out how important it is for the region to be integrated into the world space. Local names prevail, and this aspect is crucial while globalization is an upcoming trend. It emphasizes the key idea of www.74.ru website [13]: city issues. Moreover, it can be proved by repeating a few local place names. They are Chelyabinsk (namely $8+6$ times used in the phrase Chelyabinsk citizen which is a single word in the Russian language) and South Ural (used 5 times).

The following groups of place names have been found:

Oikonyms: Churilovo, Zlatoust, Chelyabinsk, Ussuriisk;

Horonyms: Ukraine, South Ural;

Minor place names:

Ergonyms: $S 7$ (airlines), Intersvyaz, Medeor (clinic), $M M K$, RC Zarya;

Agoronym: Dovator marketplace;

Dovator marketplace can be abridged to Dovator that originates from the corresponding hodonym.

Ergonyms mentioned are particularly familiar to Chelyabinsk citizens and inseparably associated with either the city (Intersvyaz) or the region $(M M K)$.

Moreover, there is one prominent feature in the discourse: the frequent usage of abbreviations connected with place and space. The webpage updated on April 1, 2019 includes eight abbreviations (Minsots, $R C, K V N$, $M M K$, STSI, gorzdrav, MUP, ChelyabGET) which makes up to almost $10 \%$ of the used common and proper names of urban nouns.

Since the website of Yekaterinburg [14] does not have any central news column but only "bars" or "tiles" of news, we have chosen the first 28 headings for analysis (the same number as in the study of www.74.ru [13]). The webpage of www.66.ru [14] is also updated on April 1, 2019, it includes the following place names (italicized examples) and city space verbal markers in the order listed in this website. FSB (abbreviation for Federal Security Service of Russia), SvZD (abbreviation for Sverdlovsk Railways); Mintrud (abbreviation for Ministry of Labour); Supreme Court; Ural (adj.); Rifey (Northern mountains in Greek mythology, synonym to Ural mountains) technical high school; KommersantUral editorial office; list of CEOs; Yekaterinburg (5). There are also nearby towns; industrial centers; Airlines Pobeda; restaurant; summer camp; ISS (Immigrant Social Services); flats; Ural cyberschool; Europe; Victory Parade; map of road blockings; Sverdlovsk 
regional court; Russia; Crimea; Caucasus; Vayner (street name); intensive care; new buildings; gas stations; courts; Science Town, city; police state.

As in www.74.ru [13] website the place names and verbal city space markers of www.66.ru [14] present both regional news and world and country news. The latter include ISS, Europe, Russia, Crimea and Caucasus, Pobeda airlines. The ratio of the wider space news is 6 to 4 compared with the website of Chelyabinsk. It means that the website of Yekaterinburg presents city image as being more integrated in the world and country affairs. Moreover, the frequency of mentioning the name of the region is also lower. Yekaterinburg is mentioned 5 times, Sverdlovsk region is mentioned 2 times, Ural is mentioned 3 times (compared to the total number of 19 references in www.74.ru [13]). There are 4 abbreviations ( $F S B, S v Z D$, Mintrud, ISS) which makes up $11 \%$ and is similar to the data of www.74.ru [13].

The following place names groups have been outlined in www.66.ru_[14]:

Oikonyms: Yekaterinburg;

Horonyms: Sverdlovsk (region), Ural, Europe, Russia, Crimea, Caucasus;

Ergonyms: $S v Z D$, Rifey technical high school, Kommersant-Ural, Pobeda Airlines;

Dromonym: $S v Z D$;

Hodonym: Vayner.

Unlike www.74.ru [13], the website of Yekaterinburg contains only one local commercial place name (technical high school Rifey). Other ergonyms are either all-Russian branches ( $S v Z D$ as a part of RZD, Kommersant-Ural, Pobeda Airlines).

\subsection{Discussed issues}

World, Russian and local place names and city space verbal markers, problems and topics discussed in the articles and mentioned in headings define the image of a city and its language culture.

The central news column of Chelyabinsk website [13] offers an article on social issue as the leading story being illustrated by a photo collage. Other five headings which can be seen without scrolling and consequently may be considered as the prime ones are dedicated to health (2), community and industry problems. After scrolling one can read other 7 headings which we mark as second priority. They are about crime, community, new technologies, business and politics. The topics of the third priority news include: law and crime (7), community and social problems (5), industry and business (3), healthcare (1). However, viewers rarely scroll down the end of the page and they are of less importance. As a result, the news topics leaders are law/crime topics and social/community problems with 7 references each. Having 3 references, industry/business topics and health issues rank second. These figures reflect a cross-like balance system of city news (Fig. 1).

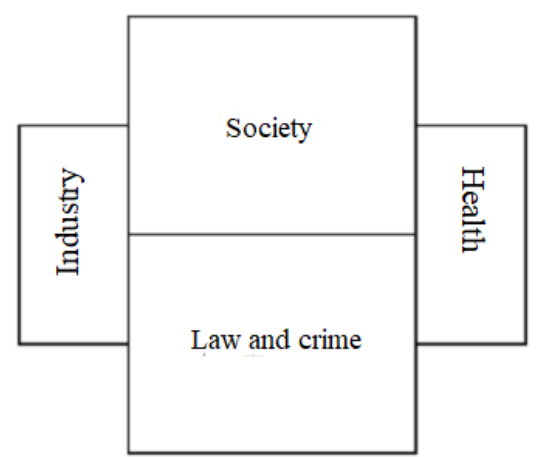

Fig. 1. Cross-like balance system of city news [13]

The website has standing heads situated to the right of the central news column. On the one hand, it is convenient; on the other hand, it echoes constant tabs, which is unnecessarily. The standing heads are business, real estate, transport, health, rest, education.

There is one characteristic that is special for www.74.ru [13], that is the representation of news of its media competitors and partners (www.chelyabinsk.ru, www.mychel.ru, www.chel.ru, www.transport74.ru, www.auto.ru, www.cheldoctor.ru, www.cheldiplom.ru), which can be seen after scrolling.

The website of Yekaterinburg [14] begins with legal and criminal news (six out of first eight pieces of news are dedicated to these topics). Government, commercial, health, tourism topics are limited to one reference out of the first 12 pieces of news (except for industrial topic which has two references). Then one can read 4 articles dedicated to social issues and 2 headings partially consider transport problem. Subsequent articles discuss similar issues: industry, community and crime. It can be graphically depicted as a pyramid representing the most popular city issues where crime is the basement, the second layer belongs to society and the third layer is industry (Fig. 2). Other topics may vary and do not greatly influence the general image of the city giving it a bit of a versatile character.

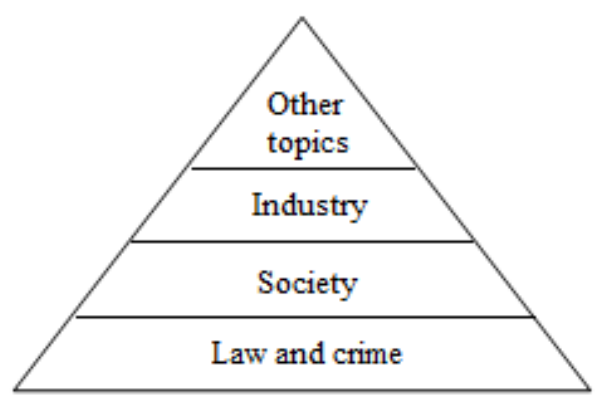

Fig. 2. Pyramid-like balance system of city news [14]

Despite the fact that Yekaterinburg website [14] gives an opportunity to cover only pleasant news content by choosing "good news" button, the number of its followers in www.vk.com social network is only a bit more than 83000 people while www.74.ru [13] website has more than 260000 people (the population of the two cities is approximately the same). It shows that social 
issues discussed in the articles are of greater importance for viewers and more attractive for its audience.

\section{Discussion}

To trace the development of websites and topic changes as well as to define the major characteristics of the analyzed city space the website updating over a period of two months with the intervals of one week has been studied. The tables below represent the research results of www.74.ru [13] at the interval of one week (Table 1) and the data of www.66.ru [14] at the interval of one and a half month (Table 2).

Table 1. Frequency of toponyms connected with the region [13]

\begin{tabular}{|l|l|}
\hline April, 1 & April, 9 \\
\hline \multicolumn{2}{|c|}{ Place names } \\
\hline Chelyabinsk (14) & Chelyabinsk (17) \\
South Ural (5) & South Ural (4) \\
Medeor (clinic) & "Yuzhuralmost" (2) \\
Zlatoust & "Taganay-2020" \\
Churilovo & "Kalinka" \\
RC Zarya (means & South Ural State \\
Residential Complex & University \\
"Dawn") & Churilovo \\
"Intersvyaz" & Lake Turgoyak \\
S7 (airlines) & "Chelyabinsk pine wood" \\
Ukraine & \\
Ussuriisk & \\
Dovator marketplace & \\
KVN (abbreviation for & \\
Club of the cheerful and & \\
sharp-witted) & \\
MMK (abbreviation for & \\
Magnitogorsk Iron and & \\
Steel Works) & \\
\hline \multicolumn{2}{|c|}{ City space verbal markers } \\
\hline Social problems, community \\
\hline queue (2) & streets (2) \\
hospital & airport (2) \\
registration desk & church \\
water pipeline company & public gardens \\
kindergarten & sport cluster \\
tv tower & roads \\
the metals & jetway \\
health resort & parking \\
flat & termity electric transport \\
clinic & the police \\
municipal unitary & fire point \\
enterprise & the post \\
civil servant & canalization \\
(department) & hotel \\
tram metals \\
busy road \\
ambulance \\
fire-fighters (station) & nood landmark \\
\hline
\end{tabular}

\begin{tabular}{|c|c|}
\hline $\begin{array}{l}\text { new building } \\
\text { tower-block }\end{array}$ & $\begin{array}{l}\text { congress-hall (3) } \\
\text { construction site (3) }\end{array}$ \\
\hline \multicolumn{2}{|c|}{ Region, government, city structure } \\
\hline $\begin{array}{l}\text { region (3) } \\
\text { suburbs } \\
\text { city hall } \\
\text { land } \\
\text { town } \\
\text { frontier guard } \\
\text { the police }\end{array}$ & $\begin{array}{l}\text { city }(2) \\
\text { village } \\
\text { region } \\
\text { administration } \\
\text { city hall } \\
\text { city administration }\end{array}$ \\
\hline \multicolumn{2}{|l|}{ Phrasal space indicators } \\
\hline $\begin{array}{l}\text { all the world } \\
\text { half a km radius } \\
\text { new places }\end{array}$ & $\begin{array}{l}\text { center } \\
\text { the central part }\end{array}$ \\
\hline \multicolumn{2}{|c|}{ Abbreviations } \\
\hline $\begin{array}{l}\text { STSI (2) (State Traffic } \\
\text { Safety Inspectorate) } \\
\text { Minsots (Ministry of } \\
\text { Social Protection) } \\
\text { KVN (Club of the } \\
\text { cheerful and sharp- } \\
\text { witted) } \\
\text { MMK (Magnitogorsk } \\
\text { Iron and Steel Works) } \\
\text { MUP (Municipal } \\
\text { Unitary Enterprise) } \\
\text { gorzdrav (city } \\
\text { healthcare) } \\
\text { ChelyabGET } \\
\text { RC (Residential } \\
\text { Complex) }\end{array}$ & $\begin{array}{l}\text { FSB (Federal Security } \\
\text { Service of Russia) } \\
\text { STSI (State Traffic Safety } \\
\text { Inspectorate) } \\
\text { MChS (Ministry of } \\
\text { Emergency Situations) } \\
\text { VIP-lounge }\end{array}$ \\
\hline
\end{tabular}

Table 1 demonstrates that the frequency of toponyms connected with the region (Chelyabinsk, South Ural) remains comparatively the same and considerably prevails in every updating. Toponyms cover not only the city but the region as well (Zlatoust, Lake Turgoyak). The number of trade names is similar (3 and 2 respectively: Medeor, Intersvyaz, S7, Yuzhuralmost, Kalinka). The permanent usage of trade names is an inherent characteristic of www.74.ru [13] making advertising space accessible and attractive for viewers.

Table 2. Frequency of toponyms connected with the region [14]

\begin{tabular}{|l|l|}
\hline April, 1 & May, 17 \\
\hline \multicolumn{2}{|c|}{ Place names } \\
\hline Yekaterinburg (5) & Yekaterinburg (5) \\
Ural (2) & Drama (2) \\
"Rifey" & Yeltsin-Center \\
"Kommersant-Ural" & Ural \\
(editorial) & St Ekaterina church \\
Airlines "Pobeda" & "May walkings" (route) \\
Europe & Sheremetyevo \\
Sverdlovsk & Makarov bridge \\
Russia & "Zolotoy" (shopping mall) \\
Crimea & Perm \\
Caucasus & "Solaris" (Residential \\
Vayner (street) & complex) \\
& "Dinamo" \\
& "Bay \\
\hline
\end{tabular}




\begin{tabular}{|c|c|}
\hline & $\begin{array}{l}\text { Queens"(Residential } \\
\text { complex) } \\
\text { China } \\
\text { Kazakstan } \\
\text { Belarus } \\
\end{array}$ \\
\hline \multicolumn{2}{|c|}{ Cyberspace } \\
\hline & $\begin{array}{l}\text { 66.ru } \\
\text { YouTube }\end{array}$ \\
\hline \multicolumn{2}{|c|}{ City space verbal markers } \\
\hline \multicolumn{2}{|c|}{ Social problems, community } \\
\hline $\begin{array}{l}\text { training college } \\
\text { restaurant } \\
\text { summer camp } \\
\text { flats } \\
\text { Victory Parade } \\
\text { map of streets shuttings } \\
\text { intensive care } \\
\text { petrol stations } \\
\text { Science town } \\
\text { Cyberschool }\end{array}$ & $\begin{array}{l}\text { public gardens (5) } \\
\text { church (3) } \\
\text { park (2) } \\
\text { kiosk }\end{array}$ \\
\hline \multicolumn{2}{|l|}{ Industry, business } \\
\hline $\begin{array}{l}\text { table of CEO } \\
\text { industrial centers } \\
\text { new buildings }\end{array}$ & $\begin{array}{l}\text { construction site (2) } \\
\text { shopping mall (2) } \\
\text { Bank Uralsib (2) }\end{array}$ \\
\hline \multicolumn{2}{|l|}{ Region, government } \\
\hline $\begin{array}{l}\text { Supreme Court } \\
\text { regional court } \\
\text { courts } \\
\text { city } \\
\text { police state } \\
\text { nearby towns } \\
\end{array}$ & $\begin{array}{l}\text { city center ( } 2) \\
\text { Gorduma (city council) } \\
\text { the police } \\
\text { town } \\
\text { village }\end{array}$ \\
\hline \multicolumn{2}{|l|}{ Minor space markers } \\
\hline & $\begin{array}{l}\text { roof } \\
\text { basement } \\
\text { fence }\end{array}$ \\
\hline \multicolumn{2}{|c|}{$\begin{array}{c}\text { Abbreviations } \\
\end{array}$} \\
\hline $\begin{array}{l}\text { FSB (2) (Federal } \\
\text { Security Service) } \\
\text { SvZD (Sverdlovsk } \\
\text { Railways) } \\
\text { Mintrud (Ministry of } \\
\text { Labour) } \\
\text { ISS }\end{array}$ & $\begin{array}{l}\text { MChS (Ministry of } \\
\text { Emergency Situations) } \\
\text { URFU (Ural Federal } \\
\text { University) }\end{array}$ \\
\hline
\end{tabular}

According to Table 2. www.66.ru (Yekaterinburg) [14], place names cover a larger volume of website space than that of www.74.ru [13] as there are from 3 to 5 oikonyms and horonyms (Europe, Crimea, Caucasus, Sheremetyevo, Perm, China, Kazakstan, Belarus) in the first website. At the same time the frequency of Yekaterinburg place names is about 3 times lower than that of Chelyabinsk www.74.ru website [13]. The number of place names is also lower on www.66.ru [14] compared to the website of Chelyabinsk [13]. Moreover, it has decreased during the study (the same is true of the usage of abbreviations) while the number of place names has increased.

The website of Yekaterinburg [14] contains a unique usage of a popular folk place name for the place near the drama theatre - Drama. The folk place name usage makes Yekaterinburg website language more colloquial and targeted at the local website users. It may be supposed that the number of folk place names mentioning will only increase in the future on both websites making their language less official.

\section{Conclusion}

The two large Ural websites study has proved that city place names and minor place names as well as various general city space markers create a unique city image, on the one hand, and realize universal characteristics of a modern city image by using general city space lexicon, by repetitive choice of topics, actual city issues, on the other hand. Website language culture reflects the local city language culture in general making website material recognisable for viewers.

\section{Acknowledgment}

The research is conducted with the financial help of the Grant of Perspective Scientific Researches of Chelyabinsk state university, №126-1 dated 04.03.2019

\section{References}

1. S. Yu. Dvinina, Vest. Irkutskogo gosud. ling. univ. Space and time interaction in literary discourse, 1 (26), 90-95 (2014)

2. S. A. Pitina, G.V. Urvantsev, Vopr. kognit. lingv., Urban onomasticon in fiction and cinema discourse, 1, 17-23 (2018)

3. R. M. Amirova, Philolog. nauki, vopr. teor. i prakt., Functioning of Kazan commercial ergonyms in the context of bilingualism, 1 (57), 74-77 (2016)

4. E. L. Berezovich, Russian toponymy in ethnolinguistic aspect: Space and a man (Knizhnyi dom 'LIBROKOM', Moscow, 2009)

5. N. D. Golev, L. M. Dmitrieva, Integration of ontological and mental existence of toponymic system (to the question of cognitive toponymy), Vopr. onomastiki, 5, 5-18 (2008)

6. E. A. Jakovleva, Vestnik Nizhegorodskogo univ. im. N. I. Lobachevskogo, Philological urbanology : new aspects of city study, 6 (2), 771-774 (2011)

7. T. V. Khvesko, Kognit. issled. jazyka, Cognitive interpretation of onyms, 26, 367-369 (2016)

8. N. A. Prokurovskaja, A city in the mirror of its language (based on language materials of Izhevsk) (Izd-vo Udmurtskogo univ., Izhevsk, 1996)

9. E. S. Samsonova, Vestnik Tomskogo gosud. pedag. univ., Functioning of foreign languages means in ergonomy, 6 (96), 16-20 (2010)

10 . V. Superanskaja, General theory of a proper noun (URSS, Moscow, 2007)

11. G. R. Stewart, A Concise and Selective Dictionary for the Continental United States of America (Oxford Univ. Press, New York, Oxford, 1970) 
12. A.V. Urazmetova, Ju. Kh. Shamsutdinova. XLinguae Journal, Principles of place names classifications, 4 (10), 26-33 (2017)

13. News of Chelyabinsk, the Home Page of Website '74.ru'. Retrieved from www.74.ru (2019)
14. Here Everyone Learns Everything, the Home Page of Website '66.ru'. Retrieved from www.66.ru (2019) 